\section{TOS MeEtings-A Great Place TO MEET}

$\mathrm{T}$ HIS ISSUE FOCUSES on the TOS 1997 Meeting in Seattle. Unfortunately, due to space limitations of the magazine, we were unable to include more of the papers given at the meeting. TOS meetings have an unusual format with a focus on invited presentations. A normal day begins with a morning of presentations, followed by an afternoon of poster presentations, and a final plenary session that covers a very broad topical area.

This format is appealing because it gives all of us a chance to hear a particular topic discussed by the leading experts: "From the horse's mouth" so to speak. I think it is also beneficial for the younger oceanographers to have the opportunity to meet and hear the older oceanographers summarize their knowledge and thus "pass the torch" or at least learn what must be passed! The format of the TOS meeting allows this to happen. The meetings have not been without problems but with a strong program committee in place and an energetic Council I sense the meetings will gain historic vigor.

We all have more than enough meetings to attend but I believe that the TOS meetings have added value over the others. Come to the Paris meeting in 1998 where you can meet colleagues from Europe in an exciting setting at the International Oceanographic Commission headquarters. In 1999, the biennial meeting of TOS will be held in the U.S.. as always. The Meeting Committee is considering Baltimore, Tampa/St. Petersburg, New Orleans, and San Antonio.

—Larry Atkinson

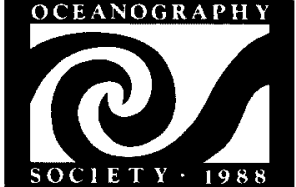

THE OCEANOGRAPHY SOCIETY

4052 Timber Ridge Drive Virginia Beach, VA 23455 USA (757) 464-0131; fax: (757) 464-1759

OFFICERS

Robert A. Duce, President Kenneth Brink, President-Elect Melbourne G. Briscoe, Secretary David Evans, Treasurer

Margaret Leinen, Past-President

COUNSELORS

Ann Gargett

Larry Mayer

Bess Ward

Larry Atkinson

Kenneth Brink Anthony Knap

Robert F. Anderson Rick Spinrad

EXECUTIVE DIRECTOR Judi Rhodes

CORPORATE/NSTITUTIONAL SPONSORS Monterey Bay Aquarium Research Institute, Pacific Grove, CA, USA

National Marine Fisheries Service,

Silver Spring, MD, USA

Ober, Kaler, Grimes \& Shriver

Washington, DC, USA

RD Instruments, San Diego. CA USA

Scripps Institution of Oceanography.

La Jolla, CA, USA

\section{OCEANOgRaphy}

CO-EDITORS

Larry $P$. Atkinson

Center for Coastal Physical Oceanography

Old Dominion University

Crittenton Hall

Norfolk, VA 23529

(757) $683-5558$

Internet: atkinson@ccpo.odu.edu

Connie Sancetta

National Science Foundation

Ocean Sciences Division Room 725

4201 Wilson Blvd.

Arlington. VA 22230

(703) 306-1586

Internet: csancett@ nsf.gov

ASSOCIATE EDITORS

James W. Ammerman

Department of Oceanography

Texas A\&M University

College Station, TX 77843 USA

(409) $845-5105$

Gregg J. Brunskill

Australian Institute of Marine Science

PMB No. 3, Townsville, M.C

Queensland 4810. Australia

(077) 789 211: FAX (077) 725852

Internet: g brunskill@aims.gov.au 